\section{Sir Patrick Laidlaw, F.R.S.}

Sir Patrick Laidlaw died on March 19 in his fifty-ninth year. His death is a major loss to medical science and a most grievous blow to all those who were privileged to know him personally.

Patrick Playfair Laidlaw, the son of Dr. R. Laidlaw, who was medical officer in the Seychelles, was borm on September 26, 1881. A family removal to Cambridge enabled him to enter the Leys School, and from school he proceeded to St. John's College with a scholarship. He completed his medical course at Guy's Hospital and graduated B.Ch.(Camb.) in 1907.

Whilst still a student at Cambridge, Laidlaw gave evidence of his remarkable gifts for research by the publication of several papers on anatomical subjects and one outstanding piece of work on blood pigments. After a few years as demonstrator of physiology at Guy's, he joined the staff of the Wellcome Physiological Research Laboratories, and there, during the next five years (1909-14), he published, either alone or with his colleagues, more than a score of papers on pharmacological subjects, the best known of which is the classical work on histamine, carried out in collaboration with H. H. Dale. This happy and fruitful association with Dale was temporarily broken in 1914 when Laidlaw returned to Guy's as lecturer in pathology, but was renewed in 1922 when he was invited to rejoin the staff of the National Institute for Medical Research. Although never very happy in his academic teaching posts, Laidlaw's strenuous war years at Guy's had helped to give him the remarkable depth and width of knowledge in several medical sciences, which rapidly bore fruit in the new environment. He collaborated in important protozoological and biochemical investigations, but it is for his pioneer researches on virus diseases that he will be most especially remembered.

Laidlaw's study of canine distemper in collaboration with G. W. Dunkin will long remain a model for those engaged in virus research. In a series of papers they described the pathology of the disease in dogs and ferrets, brought forward irrefutable proof that the disease agent concerned is a filterable virus, and finally reported the successful immunization of dogs and ferrets by means of formolized virus vaccines. The outstanding importance of this work was immediately recognized and their method of prophylaxis adopted in veterinary practice.

His next major research was on influenza. Together with C. H. Andrewes and Wilson Smith he succeeded, in 1933, in isolating a virus from patients. This discovery provided a new basis from which to attack the many problems presented by epidemic influenza, and Laidlaw with his colleagues spent the next three years in laying the foundations of our newer knowledge of the disease. On his appointment as deputy director of the National Institute in 1936, he took a less active share in the influenza work but remained always at the service of those who carried it forward. On the outbreak of the War he turned with fresh enthusiasm to new virus problems, and continued working at them until the day of his death.

Laidlaw's work brought well-deserved recognition in his later years. He was elected a fellow of the Royal Society in 1927, was awarded its Royal Medal in 1933, and was elected F.R.C.P. in 1934. The following year he was honoured with knighthood. Shortly before his death he became an honorary fellow of his old college, St. John's, Cambridge.

It is not, however, as a famous man that Laidlaw will be mourned by those who knew him well, but as a wise and ever-helpful colleague, a generous and most loyal friend. Of a shy and reserved disposition, he shunned the limelight and detested anything which savoured of self-advertisement. His keen critical faculty was at the service of those who sought his advice, but was most constantly directed against himself and his own work. His curiosity had no bounds and urged him to incessant probings in new directions, so that his 'unsuccessful' experiments were a constant stimulus and source of inspiration to those around him. Well might he have said with Leeuwenhoek, "The work which I've done for many a long year was not pursued in order to gain the praise I now enjoy but chiefly from a craving after knowledge."

W. S.

\section{Prof. E. Branly}

Prof. Edouard Branly, the inventor of the coherer, which enabled Marconi to develop wire. less communication and who is known in France as the 'father of wireless', died on March 25 at the age of ninety-five. He was born at Amiens on October 23, 1844, and after showing great brilliance as a schoolboy entered the Ecole Normale. In 1868 he became a professor at the Lycée of Bourges.

Branly's bent, however, was for research work. He therefore went to the Sorbonne and took up work in the physical laboratory and began his study of electricity and magnetism. He was a poor man, and in order to become self-supporting he qualified as a medical man and practised medicine for about twenty years, spending all his spare time in electromagnetic research, for which he received the degree of doctor of science. In 1873 he went to the Institut Catholique in Paris, where he set up a small laboratory, and it was here that his investigations led to the discovery that the electrical resistance between loose particles of metal, such as iron filings in contact with one another, diminishes under the influence of electric action.

In 1872, Branly published a paper on the "Measurement of the Intensity of Currents by the Electrometer" ; in 1892, one on "The Electrical Resistance at the Contact of Two Metals", and in 1893 one on "The Property of Discharging Electrified Bodies Produced in Gases by Incandescent Bodies: and by Electric Sparks" and in the same year, one on the "Resistance of Thin Metallic Films". The last four of these papers were published in abstract in the Journal of the Institution of Electrical Engineers.

Branly made a series of observations into the varia. tions of conductivity of a large number of materials under varying electrical influences. He found that substances which responded best to the phenomenon 